\title{
Nonsteroidal Antiestrogen Suppresses Protein Kinase C-Its Inhibitory Effect on Interaction of Substrate Protein with Membrane
}

\author{
Keisuke Edashige ${ }^{\mathrm{a}}$, Eisuke F. Sato ${ }^{\mathrm{b}}$, Kunihiro Akimaru ${ }^{\mathrm{b}}$, Tamotsu Yoshioka ${ }^{\mathrm{c}}$ and Kozo Utsumi ${ }^{\mathrm{b}, 1}$ \\ ${ }^{a}$ Institute for Laboratory Animals, Kochi Medical School, Kochi 783, bDepartment of Medical Biology, Kochi \\ Medical School, Kochi 783, and ${ }^{\circ}$ Medical Science Laboratory, Center for Adult Diseases, Kurashiki, Kurashiki \\ 710, Japan
}

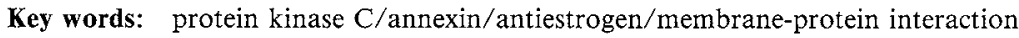

\begin{abstract}
$A B S T R A C T$. The mechanism by which nonsteroidal antiestrogen inhibits $\mathbf{C a}^{2+}$ - and phospholipid-dependent protein kinase (PKC) activity was investigated. Antiestrogenic agents, clomiphene and tamoxifen, inhibited the PKC-dependent phosphorylation of histone and r-annexin I in a dose-dependent manner. Ki values for the agents were different for two substrate proteins. The inhibitory action of the agents depended on the membranesubstrate protein interaction. Phosphorylation of cytoplasmic proteins obtained from rat uterus and mammary gland, including annexin I, by endogenous PKC was also inhibited by low concentrations of these agents. These results suggest that the inhibitory action of nonsteroidal antiestrogens occurs through their inhibitory effect on the membrane-substrate protein interaction.
\end{abstract}

Clomiphene and tamoxifen are nonsteroidal antiestrogens which are widely used for chemotherapy of infertility and breast cancer, respectively. It has been generally accepted that these agents appear to compete with estrogen for its receptor and inhibit the translocation of the estrogen receptor complex from cytosol to the nucleus, thereby suppressing the physiological functions of estrogen (1-4). Based on the observations that some biological effects of the agents could not be reversed by estrogen (4-6), however, mechanisms for the drug actions other than such simple competition have been postulated.

Recent studies suggested the possibility that $\mathrm{Ca}^{2+}$ - and phospholipid-dependent protein kinase (PKC) might be involved in the inhibitory mechanism of clomiphene and tamoxifen (7-11). The agents inhibited the phosphorylation of histone by PKC obtained from human ovary $(7,9)$, placenta (7) and rat brain (8-10). Tamoxifen inhibited the PKC-dependent phosphorylation of synthetic peptide by all subspecies of PKC purified from the breast cancer cell line (11). Phosphorylation of cytoplasmic proteins of rat ovary by endogeneous PKC was also inhibited by tamoxifen (9). However, the precise mechanism for the inhibitory action of these antiestro-

\footnotetext{
${ }^{1}$ To whom correspondence should be addressed.

Abbreviations used: $\mathrm{CBB}$, Coomassie brilliant blue; DPPC, dipalmitoylphosphatidylcholine; PS, phosphatidylserine; $\mathrm{PKC}, \mathrm{Ca}^{2+}$ phospholipid-dependent protein kinase; PMSF, phenylmethylsulfonyl fluoride; r-annexin I, recombinant annexin I; TPA, 12-0-tetradecanoyl phorbol-13-acetate.
}

gens were not elucidated.

$\mathrm{PKC}$ is a $\mathrm{Ca}^{2+}$-dependent membrane-binding protein (12). Binding to the cell membrane and the activation of PKC require acidic phospholipids, such as phosphatidylserine (PS). Activation of PKC closely correlates with the mobilization of intracellular $\mathrm{Ca}^{2+}$ and the activation of phospholipases. PKC has been assumed to be a key regulatory enzyme in many cellular events (12). Thus, it is plausible to consider that the biological action of nonsteroidal antiestrogen might depend, at least in part, on their inhibitory effect on PKC.

Another type of $\mathrm{Ca}^{2+}$-dependent membrane-binding protein, named annexin, has been recently identified; many names are used for each member of this protein family, such as lipocortin or calpactin, and the term "annexin" with the numbering system of lipocortin has been suggested (13). Like PKC, these proteins also associate with PS containing phospholipid membranes depending on $\mathrm{Ca}^{2+}$ concentrations (14-17). Several proteins in this family are phosphorylated by $\mathrm{PKC}$, p60 $0^{\text {src }}$, insulin-receptor kinase and EGF-receptor kinase by a mechanism which requires them to bind to membranes (14, 18-23). Thus, these proteins might be useful for studying the role of membrane-substrate protein interaction in the mechanism of activation of protein kinase.

The present work discusses the mechanism by which PKC activity is inhibited by nonsteroidal antiestrogens in view of their effect on the interaction of PKC substrates with membranes. 


\section{MATERIALS AND METHODS}

Chemicals. Dipalmitoylphosphatidylcholine (DPPC), histone (type IIIS), phenylmethylsulfonyl fluoride (PMSF), clomiphene, tamoxifen and 12-0-tetradecanoyl phorbol-13 acetate (TPA) were purchased from Sigma Chemical Co. (St. Louis, MO). Bovine brain phosphatidylserine (bivalent cation free) was from Funakoshi (Tokyo, Japan). DEAE-cellulose (DE-52) and glass filter (GF/C) were obtained from Whatman Ltd. (Maidston, WI). [ $\left.{ }^{-32} \mathrm{P}\right]$ ATP was from ICN Radiochemicals (Irvin, CA). Leupeptin was obtained from Peptide Institute Inc. (Osaka, Japan). Other chemicals were from Nacalai Tesque (Kyoto, Japan).

Preparation of phospholipid vesicles. Phospholipids dissolved in chloroform and methanol $(3 / 1$, vol/vol) were evaporated in vacuo at $50^{\circ} \mathrm{C}$. The residue was dispersed in $20 \mathrm{mM}$ Tris- $\mathrm{HCl}(\mathrm{pH} 7.5)$ containing $100 \mathrm{mM} \mathrm{NaCl}$. The suspension was sonicated by a Branson Sonifier (Cell Disrupter 185) at $50^{\circ} \mathrm{C}$ for 45 min under the flow of $\mathrm{N}_{2}$ gas followed by centrifugation $(10,000 \times \mathrm{g}, 5 \mathrm{~min})(24)$ to eliminate titanium. The supernatant was used as phospholipid membranes.

Preparation of $P K C$ from rat brain. $\mathrm{PKC}$ was partially purified from the brain soluble fractions of Wistar male rats weighing 250 to $300 \mathrm{~g}$. Briefly, the brains were homogenized in $20 \mathrm{mM}$ Tris- $\mathrm{HCl}$ (pH 7.5), $0.25 \mathrm{M}$ sucrose, $10 \mathrm{mM}$ EDTA, $5 \mathrm{mM}$ EGTA, $10 \mathrm{mM} \beta$-mercaptoethanol and $0.1 \%$ Triton $\mathrm{X}$ 100 followed by centrifugation $(100,000 \times \mathrm{g}, 1 \mathrm{~h})$. The supernatant applied to a DE-52 column equilibrated with $20 \mathrm{mM}$ Tris-HCl (pH 7.5), $0.5 \mathrm{mM}$ EGTA, $0.5 \mathrm{mM}$ EDTA and 10 $\mathrm{mM} \beta$-mercaptoethanol (buffer A). The column was washed with buffer A containing $30 \mathrm{mM} \mathrm{NaCl}$. PKC was eluted from the column with buffer A containing $100 \mathrm{mM} \mathrm{NaCl}$. The DE52 fraction was applied to a TSK G-3000SW column equilibrated with $20 \mathrm{mM}$ Tris- $\mathrm{HCl}(\mathrm{pH} 7.5)$ containing $0.5 \mathrm{mM}$ EDTA, $0.5 \mathrm{mM}$ EGTA, $10 \mathrm{mM} \beta$-mercaptoethanol and 100 $\mathrm{mM} \mathrm{NaCl}$. The active fractions were collected and were used as partially purified PKC.

Preparation of uterus and mammary gland cytoplasmic proteins. Uterus and mammary gland were obtained from Wistar rats. After sacrifice by exsanguination, the abdominal skin of a pregnant rat at the 7 th day after mating was rapidly removed and the mammary gland was scraped off. The uterus at oestrus was used. The organs were homogenized with polytron homogenizer at $4^{\circ} \mathrm{C}$ in $20 \mathrm{mM}$ Tris- $\mathrm{HCl}$ buffer $(\mathrm{pH} 7.5)$ containing $0.15 \mathrm{M} \mathrm{KCl}, 1 \mathrm{mM}$ PMSF, $0.01 \%$ leupeptin, $5 \mathrm{mM}$ EDTA and $2 \mathrm{mM}$ EGTA. The homogenates were centrifuged at $100,000 \times \mathrm{g}$ for $1 \mathrm{~h}$. These supernatants were applied to a Sephadex G-25 column equilibrated with $20 \mathrm{mM}$ Tris- $\mathrm{HCl}$ (pH 7.5) and $0.15 \mathrm{M} \mathrm{KCl}$. The macromolecular fractions were used as the cytoplasmic proteins.

Preparation of annexin I. Annexin I is identical to lipocortin I, p35, calpactin II, chromobindin 9 or GIF. Recombinant annexin I (r-annexin 1) expressed in Saccharomyces cerevisiae was purified as described previously (23). Briefly, the yeast cells were disrupted with bead beader in the presence of
EGTA and protenase inhibitors followed by centrifugation at $5000 \times \mathrm{g}$ for $30 \mathrm{~min}$. $\mathrm{Ca}^{2+}$ was added to the supernatant and centrifuged at $100,000 \times \mathrm{g}$ for $1 \mathrm{~h}$. The pellet was corrected, suspended in the buffer containing EGTA and protenase inhibitors and centrifuged at $100,000 \times \mathrm{g}$ for $1 \mathrm{~h}$. The supernatant was corrected and salted out with $\left(\mathrm{NH}_{4}\right)_{2} \mathrm{SO}_{4}$ (saturation level of $100 \%$ ). The precipitate was dissolved in $25 \mathrm{mM}$ triethanolamine-iminodiacetic acid ( $\mathrm{pH} \mathrm{8.3),} \mathrm{dialyzed} \mathrm{against} \mathrm{the} \mathrm{same}$ buffer, and applied to a Mono P column. r-Annexin I was eluted with $10 \%$ polybuffer-iminodiacetic acid ( $\mathrm{pH}$ 5.0) followed by gel filtration (TSK G-3000SW). r-Annexin I was purified to homogeneity by these procedures.

Assay of $P K C$. PKC activity was assayed by measuring the incorporation of ${ }^{32} \mathrm{P}$ from $\left[\gamma-{ }^{32} \mathrm{P}\right] \mathrm{ATP}$ into substrate proteins. Protamin sulfate, histone and $\mathrm{r}$-annexin 1 were phosphorylated by rat brain $\mathrm{PKC}$ in $20 \mathrm{mM}$ Tris-HCl buffer $(\mathrm{pH}$ 7.5) containing $10 \mathrm{mM}$ magnesium acetate, $0.3 \mathrm{mM} \mathrm{Ca}^{2+}$ and $10 \mu \mathrm{M}\left[\gamma-{ }^{32} \mathrm{P}\right] \mathrm{ATP}(25)$ in the presence or absence of phospholipid. The antiestrogens were preincubated with phospholipid vesicles for $2 \mathrm{~min}$ because a certain period was needed for incorporation of the agents with the vesicles (26). The reaction was stopped by the addition of ice-cold $25 \%$ trichloroacetic acid (protamine sulfate and histone) or of SDS-PAGE sample buffer solution (r-annexin I). The phosphorylation of cytosolic proteins $(1 \mathrm{mg} / \mathrm{ml})$ by the endogenous protein kinases was carried out under the same conditions without purified $\mathrm{PKC}$, as described elsewhere (24). The phosphoproteins were analyzed by liquid scintillation counting (protamine sulfate and histone) or by the density of the film of autoradiography at $600 \mathrm{~nm}$ (r-annexin I) following SDS-PAGE (27).

Binding assay of PKC substrate proteins to phospholipid vesicles. The interaction of histone or $\mathrm{r}$-annexin I with phospholipid vesicles was analyzed by the flotation method (24, $28)$. Briefly, the PKC substrate proteins $(100 \mu \mathrm{g} / \mathrm{ml})$ were incubated with small unilamellar vesicles $(200 \mu \mathrm{M}$, DPPC or DPPC/PS, 4/1, and $100 \mathrm{nM}$ TPA) at $30^{\circ} \mathrm{C}$ for $5 \mathrm{~min}$ in 20 $\mathrm{mM}$ Tris- $\mathrm{HCl}(\mathrm{pH} 7.5), 10 \mathrm{mM}$ magnesium acetate, $50 \mathrm{mM}$ $\mathrm{NaCl}$ and $0.3 \mathrm{mM} \mathrm{Ca}^{2+}$ or $1 \mathrm{mM}$ EGTA, and then mixed with an equal volume of 1.12 density Ficoll 400 solution dissolved in $20 \mathrm{mM}$ Tris- $\mathrm{HCl}$ buffer ( $\mathrm{pH} \mathrm{7.5)} \mathrm{containing} 50 \mathrm{mM} \mathrm{NaCl}$, $10 \mathrm{mM}$ magnesium acetate and $0.3 \mathrm{mM} \mathrm{Ca}^{2+}$ or $1 \mathrm{mM} \mathrm{EGTA}$. The mixture was layered within a discontinuous Ficoll density gradient of 1.05 and 1.01 dissolved in $20 \mathrm{mM}$ Tris- $\mathrm{HCl}(\mathrm{pH}$ 7.5 ) and $0.3 \mathrm{mM} \mathrm{Ca}^{2+}$, and centrifuged at $100,000 \times \mathrm{g}$ at $30^{\circ} \mathrm{C}$ for $1 \mathrm{~h}$. The liposomes which floated upward through this gradient were collected, and analyzed by silver staining following to SDS-PAGE.

Immunoblot analysis. The presence of annexin I in the cytosol was detected by immunoblot analysis using a commercially available kit (ELC Western blotting detection system, Amersham International plc), which detects immunoreactive materials as chemiluminescence. The primary antibody used was anti-r-annexin I-rabbit antibody prepared in our laboratory. 


\section{RESULTS}

Effect of antiestrogens on protein phosphorylation by PKC. Nonsteroidal antiestrogens, such as clomiphene and tamoxifen, inhibited PKC activity. The inhibitory activity of antiestrogens differs depending on the concentration of the phospholipid used. It has been suggested that the agents inhibit PKC by way of competing with PS $(8,9)$. In the presence of $100 \mathrm{nM}$ TPA, the half-maximum concentration of phospholipid (DPPC/ PS, 4/1) for the PKC-dependent phosphorylation of histone was $17.5 \mu \mathrm{M}$ (3.5 $\mu \mathrm{M}$ for PS) (data not shown). Thus, we determined the inhibitory action of clomiphene and tamoxifen on the PKC-dependent phosphorylation of histone and annexin $I$ in the presence of $17.5 \mu \mathrm{M}$ phospholipid. The Ki values of tamoxifen and clomiphene for the phosphorylation of histone were 40 $\mu \mathrm{M}$ and $50 \mu \mathrm{M}$, respectively (Fig. 1A). However, the phosphorylation of protamine sulfate, which does not require $\mathrm{Ca}^{2+}$, PS or TPA, was not inhibited by these agents up to $200 \mu \mathrm{M}$, as reported previously $(8,10)$. Based on such observations, O'Brian et al. speculated that nonsteroidal antiestrogens might inhibit $\mathrm{PKC}$ activity by interacting with the regulatory domain of PKC rather than with its catalytic domain (8).

Annexin I is an intracellular protein that serves as a substrate for PKC. This protein associates with PS containing liposomes in a $\mathrm{Ca}^{2+}$-dependent fashion, and is phosphorylated by PKC $(14,23)$. Phosphorylation of $r-$ annexin I was inhibited by these agents in a dose-dependent manner. The Ki value of r-annexin I $(1.5 \mu \mathrm{M})$ was much lower than that of histone (Fig. 1B).
Effect of tamoxifen on the interaction of substrates with phospholipid membranes. Some amphipathic PKC inhibitors have positively charged groups $(29,30)$. As reported previously, one such inhibitor, cepharanthine, inhibited the interaction of the substrate with phospholipid membranes, and suppressed the PKC-dependent phosphorylation of proteins. Thus, we investigated the effect of antiestrogens on the interaction of histone and $\mathrm{r}$-annexin I with phospholipid membranes by the flotation method. In the flotation method, enough protein and phospholipid membranes should be added in the reaction mixture in order to detect protein and to float up protein-binding membranes through the Ficoll density gradient. In a preliminary experiment, $200 \mu \mathrm{M}$ phospholipid vesicles were needed to float up through the gradient in the presence of $100 \mu \mathrm{g} / \mathrm{ml}$ proteins. Thus, we carried out the flotation method in the presence of $200 \mu \mathrm{M}$ phospholipid and $100 \mu \mathrm{g} / \mathrm{ml}$ proteins.

Figures 2 and 3 show the inhibitory effect of tamoxifen on the association of histone and $r$-annexin I with the membranes, respectively. The association of histone with phospholipid membranes depended on the presence of PS as a constituent of the membrane (Fig. 2B). Association of histone with membranes was inhibited by tamoxifen in a concentration dependent manner; complete inhibition by tamoxifen occurred at an inhibitor concentration of $200 \mu \mathrm{M}$. The dose dependency of the inhibition of protein-membrane association closely correlated with that of phosphorylation (Fig. 2A). These results suggested that tamoxifen might inhibit phosphorylation of histone by way of decreasing its as-
A

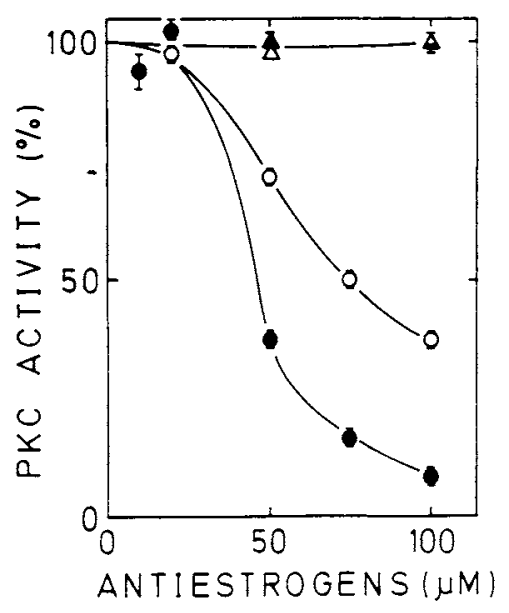

B

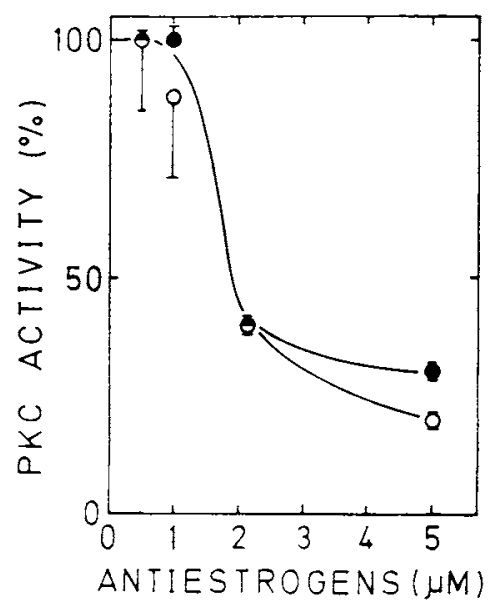

Fig. 1. Effect of antiestrogens on phosphorylation of various proteins by PKC. The reactions were performed in the presence (histone and $\mathrm{r}-$ annexin I) or absence (protamine sulfate) of $17.5 \mu \mathrm{M}$ phospholipid (DPPC or DPPC/PS, 4/1) and $100 \mathrm{nM}$ TPA. The concentrations of the substrates were $200 \mu \mathrm{g} / \mathrm{ml}$. circle: histone (A) or r-annexin I (B); triangle: protamine sulfate; closed symbol: tamoxifen; open symbol: clomiphene. The data are indicated as mean $\pm \operatorname{SEM}(n=3)$. 
A

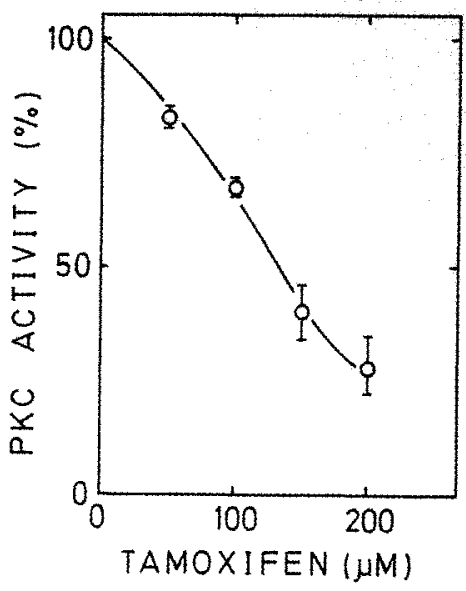

B

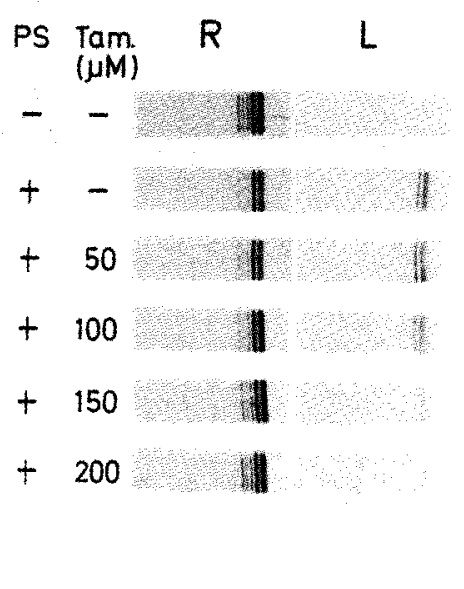

Fig. 2. Effect of tamoxifen on the interaction of histone with phospholipid membranes. Inhibitory effects of tamoxifen on the phosphorylation of histone by PKC (A), and on the association of histone with phospholipid membranes (B) were assayed in the presence of $200 \mu \mathrm{M}$ phospholipid (DPPC/PS, 4/1) and $100 \mathrm{nM}$ TPA, as described in materials and methods. The extent of association of histone with phospholipid membrane is expressed by silver staining following SDS-PAGE (15\% gel), and that of histone phosphorylation was assayed by scintillation counting. L: membrane-associated fraction; R: residual protein fraction. Bars indicate \pm SEM.

sociation with membranes.

Association of r-annexin I with phospholipid membranes required $\mathrm{Ca}^{2+}$ and PS (Fig. 3B); weak association of $\mathrm{r}$-annexin I with DPPC membrane was observed in the presence of $10^{-4} \mathrm{M} \mathrm{Ca}^{2+}$ (data not shown).

Membrane-r-annexin I association was inhibited strongly by tamoxifen; the dose dependency of the inhibition of the membrane association also closely corre- lated with the inhibition of phosphorylation (Fig. 3A). These results suggested that the inhibitory activity of tamoxifen on the interaction of histone and $r$-annexin I with phospholipid membranes might be responsible for the inhibition of PKC-dependent phosphorylation of these proteins.

Effect of antiestrogens on the phosphorylation of cytoplasmic proteins by endogenous PKC. Figure 4
A

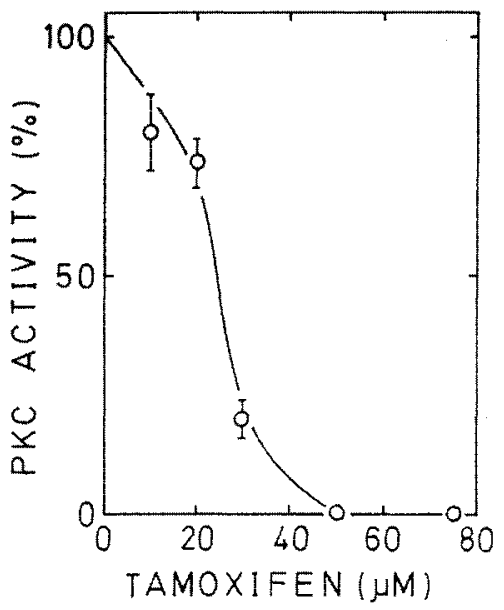

B

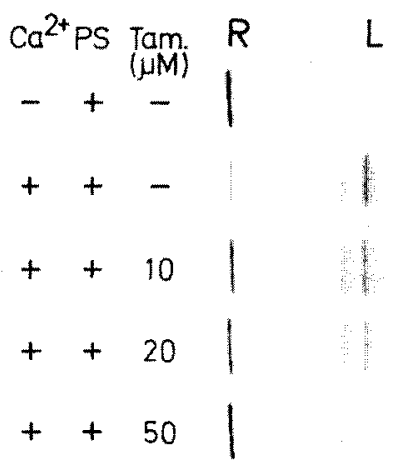

Fig. 3. Effect of tamoxifen on the interaction of $r$-annexin I with phospholipid membrane. Inhibitory effects of tamoxifen on the phosphorylation of histone by PKC (A), and on the association of histone with phospholipid membranes (B) were assayed in the presence of $200 \mu \mathrm{M}$ phospholipid (DPPC/PS, 4/1) and $100 \mathrm{nM}$ TPA, as described in materials and methods. The extent of association of r-annexin I with phospholipid membranes is expressed by silver staining following SDS-PAGE ( $12 \%$ gel), and that of phosphorylation was assayed by measuring the density of the $\mathrm{X}$-ray film of autoradiography at $600 \mathrm{~nm}$ following SDS-PAGE. L: membrane-associated fraction; R: residual protein fraction. Bars indicate $\pm \operatorname{SEM}(\mathrm{n}=3)$. 


\section{$\begin{array}{ll}\text { A. TAMOXIFEN } & \text { B. CLOMIPHENE }\end{array}$}

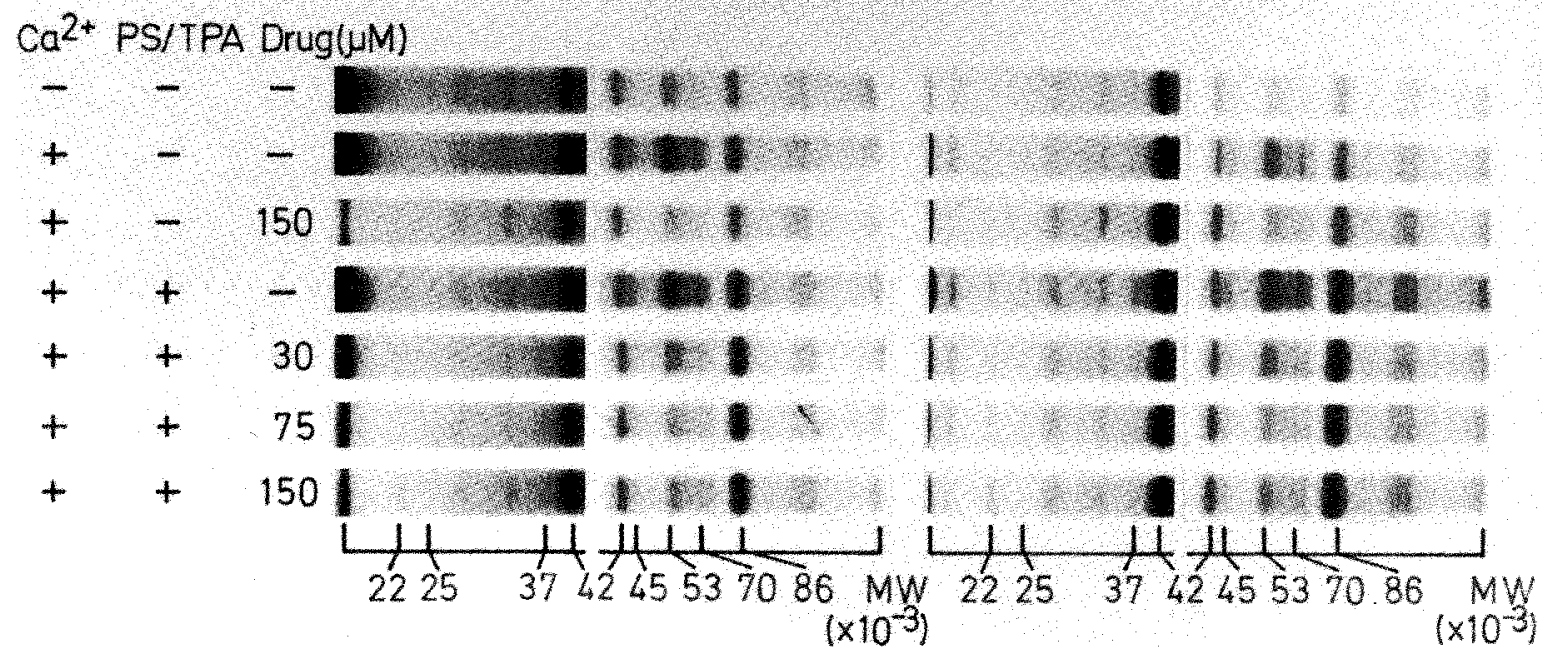

Fig. 4. Effect of antiestrogens on the phosphorylation of mammary gland cytoplasmic proteins by endogenous PKC. The inhibitory effect of tamoxifen (A) and clomiphene (B) on the PKC-dependent phosphorylation of cytoplasmic proteins obtained from rat mammary gland was analyzed by autoradiography following SDS-PAGE. The reaction was performed in the presence of $0.3 \mathrm{mM} \mathrm{Ca}{ }^{2+}, 200 \mu \mathrm{M}$ phospholipid (DPPC/PC, 4/1) and $100 \mathrm{nM}$ TPA. The reaction was stopped by addition of SDS-PAGE sample buffer followed by SDS-PAGE (10\% gel).

shows the effect of antiestrogens on the phosphorylation of cytoplasmic proteins from rat mammary gland by endogenous protein kinases. Phosphorylation of 86$80,70,56,53,45,37$ and $17 \mathrm{kDa}$ proteins was increased by $\mathrm{Ca}^{2+}$. This phosphorylation depends, in part, on PKC because of the presence of endogenous PKC activating factors; activity of purified PKC was increased by $30-40 \%$ upon addition of $\mathrm{Ca}^{2+}$ and heat denatured mammary cytosol (at $100^{\circ} \mathrm{C}$ for $3 \mathrm{~min}$ ) (data not shown). The extent of phosphorylations further increased by adding $200 \mu \mathrm{M}$ phospholipid (DPPC/PS, $4 / 1$ ) and TPA. Phosphorylation of these proteins was inhibited significantly by $30-75 \mu \mathrm{M}$ of clomiphene and tamoxifen. However, the phosphorylation of $86-80$ and $22 \mathrm{kDa}$ proteins was not affected by these agents up to $150 \mu \mathrm{M}$.

In the case of uterus cytosol (Fig. 5), phosphorylation of $100,86-80,70,60,56,37-35$ and $23 \mathrm{kDa}$ proteins

\section{A. TAMOXIFEN}

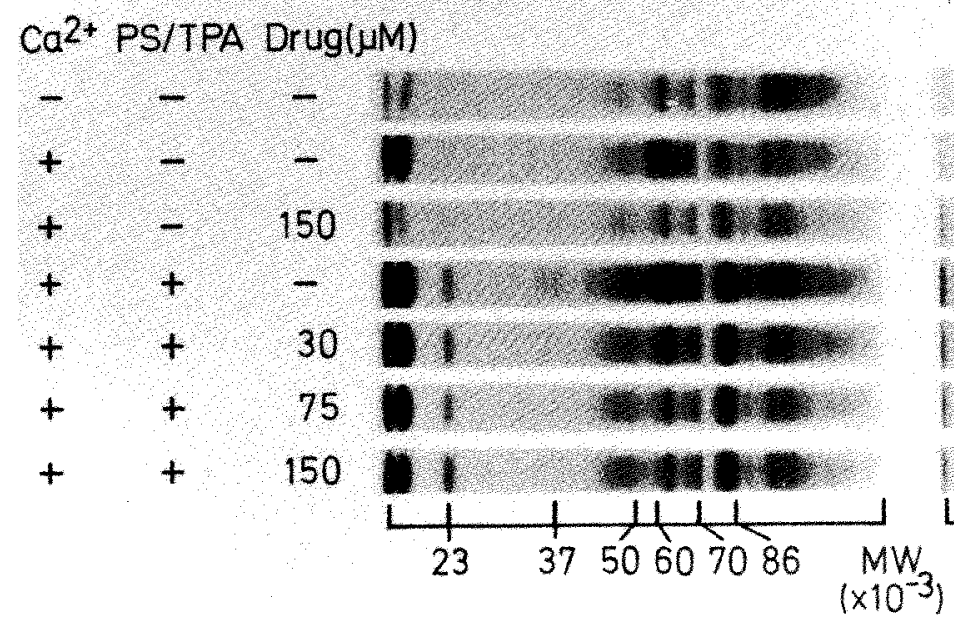

\section{B. CLOMIPHENE}

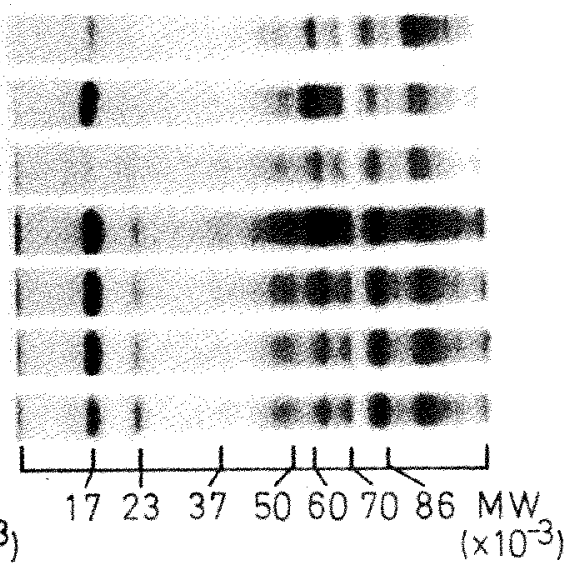

Fig. 5. Effect of antiestrogens on the phosphorylation of uterus cytoplasmic proteins by endogenous PKC. The inhibitory effect of tamoxifen (A) and clomiphene (B) on the PKC-dependent phosphorylation of cytoplasmic proteins obtained from rat uterus was analyzed by autoradiography. The experimental conditions were the same as Fig. 4. 
was increased by $\mathrm{Ca}^{2+}, 200 \mu \mathrm{M}$ phospholipid and TPA. Phosphorylation of these proteins was strongly inhibited by the antiestrogens. However, $23 \mathrm{kDa}$ protein was not inhibited by these agents up to $150 \mu \mathrm{M}$. This phosphorylation appears to depend on PKC because it requires $\mathrm{Ca}^{2+}$, PS and TPA.

These phosphoproteins were not characterized in these tissues. Since annexin I is widely distributed in many tissues, distribution of annexin I was expected in these phosphoproteins. Thus, we tested whether annexin I is presented in rat mammary gland and uterus by immunoblot analysis. The anti-r-annexin I antibody specifically reacted with annexin I from several mammals but not to other proteins of the annexin family (data not shown). As shown in Fig. 6, annexin I was detected in cytoplasmic fractions from both the rat mammary gland and uterus. The apparent molecular weight was $37 \mathrm{kDa}$ (lanes 2 and 3) as determined by SDSPAGE, which is slightly higher than that of guinea pig annexin I (Lane 1). Phosphoproteins of similar molecular weight were observed in the cytosol from the mammary gland and uterus (Figs. 4 and 5). The phosphorylations of these proteins were strongly inhibited by the antiestrogens at $30-75 \mu \mathrm{M}$ concentrations. These results in-

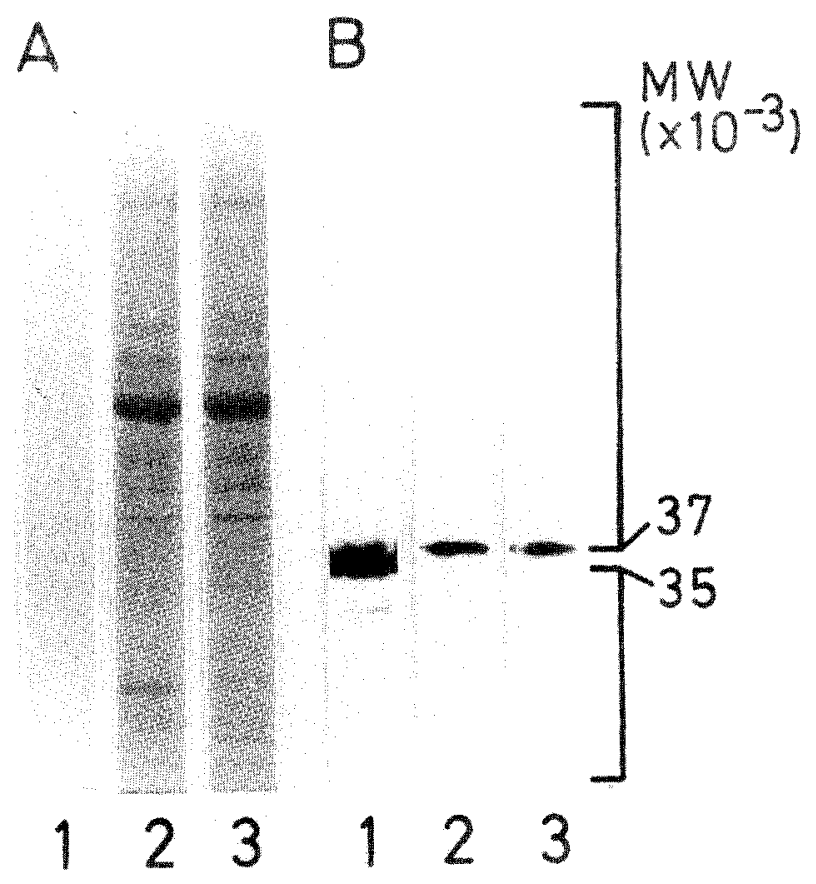

Fig. 6. Presence of annexin $I$ in rat mammary gland and uterus. Presence of annexin I in cytosol obtained from rat mammary and uterus was determined by SDS-PAGE (10\% gel) and Western blotting. (A) Coomassie brilliant blue staining. (B) Electroblotted onto Durapore filter and immunostained with rabbit antibody against $r$-annexin I. lane 1: r-annexin I (1 $\mu \mathrm{g}$ protein); lane 2 : rat mammary gland cytosol ( $50 \mu \mathrm{g}$ protein); lane 3: rat uterus cytosol (50 $\mu \mathrm{g}$ protein). dicate that PKC-dependent phosphorylation of $37 \mathrm{kDa}$ protein might include annexin $\mathrm{I}$, and that the phosphorylation was inhibited by the antiestrogens (Figs. 4 and 5).

\section{DISCUSSION}

Although it has been generally accepted that the pharmacological action of tamoxifen and clomiphene occurs by way of competition with estrogen for its receptor (14), a fairly large dose of estrogen overcame the effect of nonsteroidal antiestrogens only partially in several physiological events (4-6). Furthermore, the binding sites for nonsteroidal antiestrogens, distinct from the estrogen receptor, are present in many tissues, including the target organs of estrogen $(31,32)$.

Since the inhibitory action of tamoxifen and clomiphene on PKC activity was demonstrated, the enzyme is postulated to be one of the targets of these agents (711). These antiestrogens inhibit PKC activity by way of their competition with PS (8). Furthermore, phosphorylation of protamine sulfate, which does not require $\mathrm{Ca}^{2+}$, PS or TPA, was not inhibited by these agents. Hence, the following mechanism for the inhibition by these agents has been proposed (10): these agents interact with PS but not with the catalytic site of PKC, thereby inhibiting the enzyme action. Although nonsteroidal antiestrogens have some affinity for the regulatory domain of PKC (33), there is no indication that the agents compete with PS for the same site of this domain (26). The mechanism by which the interaction of the agents with PS inhibits the PKC activity is not understood.

The present work confirmed that the antiestrogens inhibited the phosphorylation of histone by PKC, but did not inhibit that of protamine sulfate. The effect of these agents to inhibit the phosphorylation was 5-30 times higher with $\mathrm{r}$-annexin I than with histone. These results strongly suggest that the agents inhibit the phosphorylation of r-annexin I by some mechanism other than direct inhibition of PKC activity.

Annexin I is a $\mathrm{Ca}^{2+}$ - and PS-dependent membrane binding protein. The PKC-dependent phosphorylation of annexin $\mathrm{I}$ requires $\mathrm{Ca}^{2+}$-induced association of this protein to the membrane $(14,23)$. Binding is also required for the phosphorylation of histone to PS-containing membranes $(24,34)$.

The present work demonstrates that the binding of histone and $\mathrm{r}$-annexin I to phospholipid membranes was inhibited by tamoxifen. The dose dependeney of the inhibition of membrane binding correlated well with that of phosphorylation. Buss et al. showed that inhibition of myristoylation decreased the membrane binding activity of $\mathrm{p} 60^{\mathrm{src}}$ and that nonmyristoylated p60 src was not phosphorylated by PKC (35). We previously reported that acylation of lysozyme facilitated the 
binding of the protein to phospholipid membranes and its phosphorylation by PKC (36). We also reported that cepharanthine, a biscoclaurine alkaloid and one of the PKC inhibitors, inhibited PKC activity by way of inhibiting of the membrane-substrate protein interaction (24). These observations suggest that the inhibitory effect of nonsteroidal antiestrogens on PKC might be due to inhibition of the substrate proteins to interact with phospholipid membranes. The different sensitivity of the phosphorylation of histone and $r$-annexin I to the antiestrogens might be due to the different affinity of the two proteins to membranes.

Clomiphene and tamoxifen inhibited PKC-dependent phosphorylation of cytoplasmic proteins of the rat mammary gland and uterus. Rocha and Lozano indicated the presence of several annexins in rat mammary gland, such as annexin VI ( $70 \mathrm{kDa})$, annexin II ( $36 \mathrm{kDa})$ and annexin IV (32 kDa) (37); these annexins were phosphorylated by PKC in vitro (38-41). Moreover, Kaetzel et al. indicated the presence of annexin III $(35 \mathrm{kDa})$, IV and $V(35 \mathrm{kDa})$ in the rat ovary and uterus (42). Since annexin VI $(70 \mathrm{kDa})$ is localized in muscular tissues, this protein might be localized in the uterus (43). Among various annexins, annexin I, IV and VI are phosphorylated by $\mathrm{PKC}$ in vitro $(14,40,41)$. The present work demonstrates the presence of annexin I ( $37 \mathrm{kDa})$ in the cytosol from both the rat mammary gland and uterus. The phosphoprotein with molecular weight similar to that of annexin I was also observed in the presence of $\mathrm{Ca}^{2+}$, PS and TPA. Phosphorylation of the protein was inhibited by the antiestrogens at 30-75 $\mu \mathrm{M}$, and the dose dependency corresponded to that of annexin I (Fig. 3). These results suggested that annexins in mammary gland and uterus cytosol might be phosphorylated by $\mathrm{PKC}$ and inhibited by an antiestrogen-inhibitable mechanism in which the interaction of annexins with membranous PS play critical role. Since the phosphorylation of $22 \mathrm{kDa}$ protein in the mammary gland, $23 \mathrm{kDa}$ protein in the uterus and $86-80 \mathrm{kDa}$ proteins in both tissues were not inhibited by high concentration of the agents, interaction of these proteins with membranes may not be inhibited by these agents.

Different Ki values of nonsteroidal antiestrogens for the inhibition of PKC were reported by various investigators (7-11). The reason for such differences may depend on the phospholipid concentrations used. In this study, we confirmed that increase of the phospholipid concentration increased $\mathrm{Ki}$ values for the inhibition of phosphorylation of histone and annexin I (Fig. 1, Fig. 2 and Fig. 3). The lowest Ki value of tamoxifen for PKC activity is $1-3 \mu \mathrm{M}(10)$. Since the activity of these agents to inhibit annexin I phosphorylation was 5-30 times stronger than that on histone phosphorylation, $\mathrm{Ki}$ values of these agents for annexin I phosphorylation may be of nanomolar ranges under the same experimen- tal conditions.

Clomiphene, a therapeutic agent for infertility, releases gonadotropin from the pituitary gland. Since the effective plasma level of the agent is in the nanomolar range, the mechanism of the agent might involve the competition with estrogen. Studies using primary culture cells from the pituitary gland revealed that LHreleasing hormone enhanced phosphatidylinositol turnover, and TPA-induced LH release from pituitary cells $(44,45)$. If clomiphene inhibited the PKC-dependent phosphorylation of some cytoplasmic proteins of the pituitary gland at nanomolar concentrations, the mechanism for the gonadotropin-releasing effect of clomiphene other than competition with estrogen should be considered. Further investigation is required to elucidate the molecular mechanism by which these nonsteroidal agents exert their pharmacological action.

Acknowledgements. We thank Dr. Masayasu Inoue for his most helpful discussion and critical review of this manuscript, and wish to thank Ms. Yoko Akimaru for preparing the manuscript.

\section{REFERENCES}

1. Pearson, O.H., Manil, A., and Arafah, B.M. (1982). Antiestrogen treatment of breast cancer: An overview. Cancer Res., 42: 3424-3429.

2. LipPMAN, M.E., Bolan, G., and HufF, K.K. (1976). The effect of estrogen and antiestrogens on hormone responsive human breast cancer in long term tissue culture. Cancer Res., 36: 45954601.

3. Coezy, E., Borgana, J.L., and Rochefort, H. (1982). Tamoxifen and metabolites in MCF-7 cell: correlation between binding to estrogen receptor and inhibition of cell growth. Cancer Res., 42: 317-327.

4. Reddel, R.R., MUrphy, L.C., and SUtherland, R.L. (1983). Effects of biologically active metabolites of tamoxifen on the proliferation kinetics of MCF-7 human breast cancer cells in vitro. Cancer Res., 43: 4613-4624.

5. Sutherland, R.L., Green, M.D., Hall, R.E., Reddel, R.R., and TAYLOR, I.W. (1983). Tamoxifen induces accumulation of MCF-7 human mammary carcinoma cells in the $\mathrm{G}_{0} / \mathrm{G}_{1}$ phase of the cell cycle. Eur. J. Cancer Clin. Oncol., 19: 615-621.

6. Sutherland, R.L., Hali, R.E., and Taylor, I.W. (1983). Cell proliferation kinetics of MCF-7 human mammary carcinoma cells in culture and effects of tamoxifen on exponentially growing and plateau phase cells. Cancer Res., 43: 39984006.

7. EYSTER, K.M. and ClaRK, M.R (1989). Nonsteroidal antiestrogen inhibition of protein kinase $C$ in human corpus luteum and placenta. Biochem. Pharmacol., 38: 3497-3503.

8. O'Brian, C.A., Liskamp, R.M., Solomon, D.H., and Weinstern, I.B. (1985). Inhibition of protein kinase $C$ by tamoxifen. Cancer Res., 45: 2462-2465.

9. Su, H., Mazzei, G., Vogler, W.R., and Kuo, J.F. (1985). Effect of tamoxifen, a nonsteroidal antiestrogen, on phospholipid/calcium-dependent protein kinase and phosphorylation of its endogenous substrate proteins from the rat brain and ovary. Biochem. Pharmacol., 34: 3649-3653.

10. Bignon, E., Ogita, K., Kishimoto, A., Gilbert, J., Abecassis, 
J., Miquel, J., and Nishizuka, Y. (1989). Mode of inhibition of protein kinase $\mathrm{C}$ by triphenylacrylonitrile antiestrogens. Biochem. Biophys. Res. Commun., 163: 1377-1383.

11. Bignon, E., Ogata, K., Kishimoto, A., and Nishizuka, Y. (1990). Protein kinase C subspecies in estrogen receptor-positive and -negative human breast cancer cell lines. Biochem. Biophys. Res. Commun., 171: 1071-1078.

12. NishizUKA, Y. (1986). Studies and perspectives of protein kinase C. Science, 233: 305-312.

13. Crumpton, M.J. and Dedman, J.R. (1990). Protein terminology tangle. Nature, 345: 212.

14. SchlaEpfer, D.D. and Haigler, H.T. (1987). Caracterization of $\mathrm{Ca}^{2+}$-dependent phospholipid binding and phosphorylation of lipocortin I. J. Biol. Chem., 262: 6931-6937.

15. GlenNey, J.R.Jr., TACK, B.F., and Powell, M.A. (1987). Calpactins: two distinct $\mathrm{Ca}^{2+}$-regulated phospholipid- and actin-binding proteins isolated from lung and placents. J. Cell. Biol., 104: 503-511.

16. Pepinsky, R.B., Tizard, R., Mattaliano, R.J., Sinclair, L.K., Mrller, G.T., Browning, J.L., Chow, E.P., Burne, C., Haung, K-S., Pratt, D., Wachter, L., Hession, C., Frey, A.Z., and WALlNER, B.P. (1988). Five distinct calcium and phospholipid binding proteins share homology with lipocortin I. J. Biol. Chem., 263: 10799-10811.

17. Utsumi, K., Sato, F., Oktmasu, E., Miyahara, M., and TAKAHASHI, R. (1986). Calcium-dependent association of 33 $\mathrm{kDa}$ protein in polymorphonuclear leukocytes with phospholipid liposomes containing phosphatidylserine or cardiolipin. FEBS Lett., 201: 277-281.

18. GlenNeY, J.R.Jr. (1985). Phosphorylation of p36 in vitro with pp60sre regulation by $\mathrm{Ca}^{2+}$ and phospholipid. FEBS Lett., 192: 79-82.

19. FAva, R.A. and Cohen, S. (1984). Isolation of a calcium-dependent 35-kilodalton substrate for the epidermal growth factor receptor/kinase from A-431 cells. J. Biol. Chem., 259: 26362645.

20. Karasik, A., Pepinsky, R.B., Shomlson, S.E., and Kahn, C.R. (1988). Lipocortins I and II as substrates for the insulin receptor kinase in liver. J. Biol. Chem., 263: 11862-11867.

21. SChLAEPFER, D.D. and HAIGler, H.T. (1988). in vitro Protein kinase $\mathrm{C}$ phosphorylation sites of placental lipocortin. Biochemistry, 27: 4253-4258.

22. Michener, M.L., Dawson, W.B., and Creutz, C.E. (1986). Phosphorylation of a chromaffin granule-binding protein in stimulated chromaffin cells. J. Biol. Chem., 261: 6548-6555.

23. Sato, E.F., Tanaka, Y., Edashige, K., Kobuchi, H., Morishita, S., Sugino, Y.M., Inoue, M., and Utsumi, K. (1989). Expression of the cDNA encoding lipocortin-like 39 $\mathrm{kDa}$ protein of guinea pig neutrophils in yeast. FEBS Lett., 255: 231-236.

24. Edashige, K., Utsumi, T., and Utsumi, K. (1991). Inhibition of 12-0-tetradecanoyl phorbol-13-acetate promoted tumorigenesis by cepharanthine, a biscoclaurine alkaloid, in relation to the inhibitory effect on protein kinase C. Biochem. Pharmacol., 41: 71-78.

25. BonI, L.T. and RANDO, R.R. (1985). The nature of protein kinase $\mathrm{C}$ activation by physically defined phospholipid vesicles and diacylglycerols. J. Biol. Chem., 260: 10819-10825.

26. Bignon, E., Pons, M., Gilbert, J., and Nishizuka, Y. (1990). Multiple mechanisms of protein kinase $C$ inhibition by triphenylacrylonitrile antiestrogens. FEBS Lett., 271: 54-58.

27. LAEMMLI, U.K. (1970). Cleavage of structural proteins during the assembly of the head of bacteriophage $T_{4}$. Nature, 227: 680-
685.

28. Utsumi, K., Okmasu, E., Takehara, Y., Watanabe, S., Mryahara, M., and Moromizato, Y. (1981). Interaction of cytoplasmic proteins with liposomes and their cell specificity. FEBS Lett., 124: 257-260.

29. Mori, T., Takai, Y., Minakuchi, R., Yu, B., and Nishizuka, Y. (1980). Inhibitory action of clorpromazine, dibcaine, and other phospholipid-interacting drugs on calcium-activated, phospholipid-dependent protein kinase. J. Biol. Chem., 255: 8378-8380.

30. Schatzman, R.C., Wise, B.C., and KUo, J.F. (1981). Phospholipid-sensitive calcium-dependent protein kinase: Inhibition by anti-psychotic drugs. Biochem. Biophys. Res. Commun., 98: 669-676.

31. Sutherland, R.L., Murphy, L.C., Foo, M.S., Green, M.D., Whybourne, A.M., and KRozowski, Z.S. (1980). High-affinity antioestrogen binding site distinct from the oestrogen receptor. Nature, 288: 273-275.

32. Sudo, K., Monsma, F.J.Jr., and Katzenellenbogen, B.S. (1983). Antiestrogen binding sited distinct from the estrogen receptor: subcellular localization, ligand specificity, and distribution in tissues of the rat. Endocrinology, 112: 425-434.

33. O'Brian, C.A., Housey, G.M., and Weinstein, I.B. (1988). Specific and direct binding of protein kinase $C$ to an immobilized tamoxifen analogue. Cancer Res., 48: 3626-3629.

34. Bazzy, M.D. and Nelsestuen, G.L. (1987). Mechanism of protein kinase $\mathrm{C}$ inhibition by sphingosine. Biochem. Biophys. Res. Commun., 146: 203-207.

35. Buss, J.E., Kamps, M.P., Gould, K., and Sefton, B.M. (1986). The absence of myristic acid decreases membrane binding of $\mathrm{p} 60^{\mathrm{src}}$ but does not affect tyrosine protein kinase activity. J. Virol., 58: 468-474.

36. Utsumi, T., Yoshinaga, K., Koga, D., Ide, A., Nobori, K., Okimasu, E., Terada, S., aid Utsumi, K. (1988). Association of myristylated protein with a biological membrane and its increased phosphorylation by protein kinase C. FEBS Lett., 238: $12-16$.

37. Rocha, V. and LozANo, J.J. (1990). Calcium-dependent membrane binding proteins of the mammary gland. In Stimulus Response Coupling: The Role of Intracellular Calcium-binding Proteins (V.L. Smith and J.R. Dedman, eds.). CRC Press, Boca Raton, Florida, pp443-465.

38. Johnsson, N., VAN, P.N., SOlING, H.-D., and WEBer, K. (1986). Functionally distinct serine phosphorylation site of p36. EMBO J., 5: 3455-3460.

39. Gould, K.L., Woodgett, J.R., Isacke, C.M., and Hunter, T. (1986). The protein-tyrosine kinase substrate, p36, is also a substrate for protein kinase $\mathrm{C}$ in vivo and in vitro. Mol. Cell. Biol., 6: 2738-2744.

40. Weber, K., Johnsson, N., Plessmann, U., Nguyen Van, P., Soling, H.-D., Ampe, C., and VandeKerckehove, J. (1987). The amino acid sequence of protein II and its phosphorylation site for protein kinase $\mathrm{C}$; the domain structure $\mathrm{Ca}^{2+}$-modulated lipid binding proteins. EMBO J., 6: 1599-1604.

41. Kenton, P., Johnson, P.M., and WebB, P.D. (1989). The phosphorylation of $\mathrm{p} 68$, a calcium-binding protein associated with the human syncytiotrophoblast submembranous cytoskeleton, is modulated by growth factors, activators of protein kinase $\mathrm{C}$ and cyclic AMP. Biochem. Biophys. Acta., 1014: 271281.

42. Kaetzel, M.A., Hazarika, P., and Dedman, J.R. (1990). Annexins and the search for function: an immunological first step. In Stimulus Response Coupling: The Role of Intracellular Cal- 
cium-binding Proteins (V.L. Smith and J.R. Dedman, eds.). CRC Press, Boca Raton, Florida, pp383-407.

43. Raeymaekers, L., Waytack, F., and Casteels, R. (1985). Isolation of calelectrin-like proteins associated with smooth muscle membranes. Biochem. Biophys. Res. Comm., 132: 526532.

44. LUI, T. and JACKSON, G.L. (1987). Stimulation by phorbol ester and diacylglycerol of luteinizing hormon glycosylation and release by rat anterior pituitary cells. Endocrinology, 121: 1589 1595.

45. AUDY, M.C., Boucher, Y., and Bonnin, M. (1990). Estrogen modulated gonadotropin release in relation to gonadotropinreleasing hormone (Gn-RH) and phorbol ester (PMA) action in superfused rat pituitary cells. Endocrinology, 126: 1396-1402.

(Received for publication, March 26, 1991

and in revised form, April 30, 199I) 